\title{
TEKNIK PENYELAMATAN DI AIR
}

\author{
Oleh: Wasti Danardani \\ Dosen Jurusan Pelatihan Olahraga Pariwisata, \\ (FPIK) IKIP N Singaraja
}

\section{Abstrak}

Kecelakaan dapat terjadi di mana saja, dapat menimbulkan rasa kaget, dan dapat menyebabkan kepanikan. Adanya rasa panik dapat menyebabkan korban baru sehingga dibutuhkan suatu ketenangan dan keterampilan. Pemberian pertolongan pertama pada korban kecelakaan adalah satu hal yang paling penting, karena dengan penanganan secara tepat akibat yang fatal dapat dihindarkan.

Teknik yang digunakan untuk menyelamatkan berprinsip pada ketenangan untuk dapat bertindak, dengan ketenangan dapat dipilih cara penanganan secara tepat. Langkah-langkah penyelamatan diri apabila mengalami kecelakaan di air meliputi: (1) water trap pen, (2) melepaskan pakaian, (3) mengurangi minum air, dan (4) berpegang pada benda mengapung. Teknik-teknik yang digunakan untuk menolong korban kecelakaan terbagi menjadi dua, yaitu penyelamatan dari darat dan penyelamatan langsung (turun ke air). Teknik penyelamatan dari darat dengan cara: tanpa alat, menggunakan handuk/kayu, dan gelang pelampun. Teknik penyelamatan langsung dengan cara: (1) the bip carry rescue, (2) armpit to, (3) wrist tow, dan (3) tired swimmer tow. 
Pertolongan yang diberikan pada korban sebaiknya dipilih secara tepat agar dapat menyelamatkan korban tanpa menyebabkan timbulnya cedera yang fatal. Keterampilan penyelamatan sangatlah penting dan sebaiknya dikuasai agar dapat mempertahankan diri.

Kata kunci: penyelamatan, air.

Kecelakaan dapat terjadi di mana saja, di rumah, di kantor, dalam perjalanan, bahkan ketika melakukan acara santai sekalipun. Sebuah kecelakaan dapat terjadi karena faktor ketidaksengajaan. Hal yang terjadi di luar dugaan ini menimbulkan rasa kaget dan dapat menyebabkan kepanikan. Kepanikan yang terjadi dapat menyebabkan seseorang tidak dapat berpikir secara sehat untuk mengatasi masalah yang terjadi.

Mengatasi sebuah kecelakaan tidak hanya dibutuhkan ketenangan dalam bertindak melainkan juga harus memiliki keterampilan yang memadai agar tindakan yang diambil adalah tindakan yang tepat. Keterampilan ini sangatlah penting karena dalam proses pertolongan juga mempertimbangkan keselamatan setiap orang yang terlibat dalam peristiwa penyelamatan. Jangan sampai dalam proses pertolongan terjadi penambahan korban yang berasal dari penolong, sehingga keterampilan menyelamatkan korban kecelakaan sangatlah penting dan harus diketahui oleh setiap orang karena kecelakaan tidak memilih waktu, tempat, dan siapa yang menjadi korban.

Pemberian pertolongan pertama pada korban kecelakaan adalah satu hal yang paling penting karena dengan penanganan secara tepat pada korban kemungkinan cedera yang dialami korban dapat diminimalisasi. Keterampilan menangani atau memberikan pertolongan kepada korban kecelakaan sudah familiar di masyarakat. Proses penyampaian informasi melalui banyak cara, antara lain melalui materi kesehatan pada pelajaran Penjaskes di bangku sekolah atau melalui kegiatan ekstrakurikuler seperti UKS, PMR, dan KSR. Namun demikian, materi pelatihan yang diberikan dalam kegiatan tersebut menitik beratkan pada kecelakaan yang terjadi di darat. Memang sebagian besar orang beraktivitas di darat, namun tidak menutup kemungkinan seseorang beraktivitas di air, sehingga

MEDIKORA Vol. II, No. 1, April 2006: 1 - 10. 
kemungkinan terjadinya kecelakaan di air juga ada. Oleh karena itu, keterampilan penyelamatan di air juga harus diketahui dan dikuasai.

Keterampilan penyelamatan kecelakaan di air memiliki prinsip yang sama dengan proses penyelamatan di darat, yaitu menolong tanpa menambah korban baru. Keterampilan ini dapat digunakan untuk menyelamatkan diri sendiri maupun orang lain dari kecelakaan. Pembahasan kali ini menekankan pada tindakan pertama dalam proses penyelamatan baik untuk mempertahankan diri maupun untuk menyelamatkan orang lain dan hanya membatasi pada pembahasan teknik pernyelamatan di air.

\section{TEKNIK MEMPERTAHANKAN DAN MENYELAMATKAN DIRI}

Ketika melakukan sebuah perjalanan dengan menggunakan kapal ataupun ketika melakukan liburan ke daerah perairan, tidak menutup kemungkinan dapat terjadi kecelakaan. Bahaya tidak terduga bisa mengancam diri tanpa disadari dan untuk itu perlu diketahui tindakan pertama yang harus dilakukan apabila mengalami kecelakaan tersebut. Langkah-langkah penyelamatan diri apabila mengalami kecelakaan di air sebagai berikut:

\section{Melakukan gerakan injak-injak air (water trap pen)}

Saat jatuh ke dalam air hal yang pertama dilakukan adalah bergerak menginjak-injak air atau mengayuh sepeda (water trappen) untuk menjaga agar kepala dan wajah tidak masuk ke dalam air yang dapat mengakibatkan kesulitan bernapas. Jangan berusaha untuk menginjak dasar air karena menambah ketakutan dan mengalami kepanikan yang lebih besar.

\section{Melepaskan pakaian}

apabila dalam keadaan kering pakaian yang digunakan tidak terasa berat dan tidak mengganggu dalam bergerak, akan tetapi apabila terkena air pakaian akan menjadi lebih berat dan mengganggu gerak dalam mempertahankan diri. Untuk mengurangi beban tubuh, pakaian yang digunakan lebih baik dilepaskan namun sebelum melepaskan pakaian terlebih dahulu mengetahui keadaan air. Jangan melepaskan pakaian apabila terjatuh ke dalam air yang terlalu dingin karena pakaian dapat membantu menjaga suhu tubuh walaupun beban tubuh menjadi lebih berat. 


\section{Mengurangi minum air}

Apabila terjatuh ke dalam laut, hal utama yang harus dihindari adalah air laut itu sendiri. Jangan pernah meminum air laut, air kencing, air perasan binatang laut ataupun membasahi bibir dengan air laut, hanya air hujan yang paling aman untuk diminum. Jika memiliki persediaan air tawar jangan diminum dalam waktu 24 jam pertama setelah itu dapat meminum 2 gelas per hari, namun apabila persediaan jumlah air sedikit, jumlah air yang diminum kurang lebih $100 \mathrm{cc}$ per hari.

\section{Berpegang pada benda yang dapat mengapung}

Bergerak injak-injak air tidak dapat bertahan lama untuk itu dibutuhkan alat bantu untuk mempertahankan diri agar tetap bisa berada di permukaan air. Jika tidak ada pelampung ataupun batang kayu yang dapat digunakan untuk bertahan, dapat dibuat pelampung dengan menggunakan pakaian yang digunakan. Cara membuat pelampung dari pakaian sebagai berikut:

a. Pelampung dari celana panjang

Celana yang telah dilepaskan diikatkan pada kedua bagian kaki, dapat diikat satu per satu maupun diikat menjadi satu serta kancingkan bagian pinggang. Untuk membuat celana benar-benar menjadi sebuah pelampung, celana harus diisi udara dengan cara meniup dari dalam air ataupun dengan mengibaskan celana ke arah udara dengan bagian pinggang menghadap ke bawah. Setelah celana terpenuhi oleh udara, celana dapat didekap ataupun dikalungkan di leher. Untuk mempertahankan bentuk pelampung celana, lakukan peniupan ulang setiap beberapa selang waktu.

b. Pelampung dari kemeja

Untuk kemeja dapat dibuat dengan cara mengancingkan bagian leher pada leher dan mengikat ujung-ujung lengannya serta menghadapkan bagian kancing baju pada tubuh. Kemeja akan berfungsing apabila sudah berisi udara, untuk mengisi udara dengan cara mengibaskan bagian pinggang kemeja ke luar udara dan tarik ke dalam air kemudian pegang bagian pinggang kemeja dengan erat. Apabila telah habis udaranya dapat dilakukan pengisian ulang dengan cara yang sama. Penggunaan pelampung kemeja dengan posisi telentang.

MEDIKORA Vol. II, No. 1, April 2006: 1 - 10. 
c. Pelampung dari rok bawah

Pembuatan pelampung dengan menggunakan rok lebih mudah dibandingkan menggunakan kemeja dan celana. Tetap gunakan rok dan pegang bagian bawah dengan kedua tangan lalu kibaskan rok untuk mengisi udara setelah itu rapatkan bagian bawah rok pada tubuh. Berenanglah dalam keadaan terlentang dengan bantuan pelampung rok.

\section{TEKNIK MENOLONG DAN MENYELAMATKAN ORANG LAIN}

Selain untuk menyelamatkan diri sendiri juga perlu menguasai teknik penyelamatan untuk menolong orang lain. Teknik secara umum dapat terbagi menjadi dua, yaitu teknik penyelamatan dari darat dan teknik penyelamatan langsung (mengambil korban di dalam air). Tehnik tersebut terbagi lagi menjadi beberapa teknik yang lebih rinci sesuai dengan keadaan korban. Teknik-teknik yang digunakan sebagai berikut:

\section{Penyelamatan dari darat}

Proses penyelamatan dilakukan dari darat dan menggunakan alat bantu. Biasanya korban terletak dekat dengan tepi. Tehnik yang digunakan antara lain dengan alat bantu:

a. Tanpa alat

Apabila korban dapat dijangkau dengan raihan tangan atau dengan jangkauan kaki yang terjulur yang dapat diraih oleh korban, tidak perlu alat bantu. Hal yang perlu diperhatikan adalah penolong harus memperhatikan keselamatan diri agar tidak menjadi korban berikutnya.

b. Handuk dan kayu

Handuk dan kayu adalah alat yang paling sederhana dalam membantu korban. Penggunaan alat bantu ini disesuaikan dengan jarak korban dengan tepi dan menjadi lebih aman apabila penolong tidak dapat berenang karena bantuan handuk/kayu dilakukan tanpa harus bersentuhan dengan air. Handuk/kayu diarahkan ke arah korban sedapat mungkin diarahkan bagian tangan sehingga korban dapat meraih handuk/kayu yang diberikan. 
c. Gelang pelampung

Gelang pelampung digunakan untuk korban yang berada lebih jauh ke tengah. Gelang pelampung diikatkan pada seutas tali yang digunakan untuk menarik korban yang telah berpegang pada gelang pelampung. Gelang pelampung dilemparkan ke belakang korban secara perlahan, gelang pelampung ditarik hingga korban tersangkut seperti ikan terperangap jala. Tersangkutnya korban pada gelang pelampung membuat korban berusaha meraih gelang pelampung dan setelah korban berpegangan maka tariklah denga perlahan hingga mencapai tepi.

\section{Penyelamatan langsung}

Penyelamatan langsung dilakukan apabila korban berada jauh di tengah perairan. Penyelamatan ini dilakukan oleh orang yang mahir berenang sehingga keselematan korban dan penolong dapat terjaga. Sebelum melakukan pertolongan sebaiknya penolong melakukan komunikasi dengan korban untuk mengurangi kepanikan. Korban yang berada dalam keadaan panik dapat membuat penolong ikut celaka karena dipegang terlalu erat hingga tidak dapat bergerak. Metode yang harus dikuasai terlebih dahulu adalah melepaskan diri dari pelukan korban agar dapat memberikan pertolongan lebih lanjut.

\section{Teknik Melepaskan Diri}

a. Korban memegang dari arah belakang

Rapatkan dagu pada dada, pegang bagian lengan atas korban, dan dorong tubuh ke dalam air sehingga menjauh dari korban. Setelah terlepas berputarlah dan muncul kepermukaan dan berhadapan dengan korban kemudian memberikan pelampung yang dibawa.

b. Korban memegang dari arah depan

Rapat dagu pada dada, pegang bagian lengan atau tubuh korban dan dorong tubuh ke dalam air sehingga menjauh dari korban. Keluarlah kepermukaan dan memberikan pertolongan lanjut dengan memberikan pelampung pada korban.

Setelah korban menggunakan pelampung, korban dapat dibawa ke tepi denga n cara ditarik oleh penolong yang berenang ke tepi. Apabila penolong tidak menggunakan pelampung, penolong dapat langsung menarik korban

MEDIKORA Vol. II, No. 1, April 2006: 1 - 10. 
dengan tangan ataupun mendorong korban ke arah tepi. Semua kejadian di atas dapat diatasi apabila penolong telah melihat gerak-gerik korban sehingga penolong dapat menghindari pelukan/peganggan erat dari korban dengan cara melakukan blocking dengan menggunakan kaki ataupun tangan. Blocking dilakukan dengan cara meletakkan telapak kaki atau tangan pada bagian dada korban kemudian melakukan ayunan sehingga korban terjauh dari penolong kemudian pertolongan baru bisa dilakukan.

\section{TEKNIK MEMBAWA KORBAN DARI TENGAH PERAIRAN KE TEPI}

Proses pertolongan, seorang penolong dapat melakukan seorang diri untuk membawa korban dari tengah perairan ke tepi. Adapun teknik yang dapat digunakan tanpa menggunakan alat bantu:

\section{The hip carry rescue}

Membawa korban dengan menggunakan gaya dada terbalik serta kedua tangan memeganggi korban. Cara memegang korban yaitu menyilangkan salah satu tangan dari bawah lengan dan menyilang di depan dada korban dan dikaitkan pada tangan satunya. Posisi kepala berada di bahu tempat tangan penolong yang digunakan untuk menyilang. Keadaan korban harus diperhatikan agar wajah terutama hidung dan mulut tidak terkena riak air.

\section{Armpit tow}

Cara kedua ini untuk menolong korban yang masih dalam keadaan sadar tetapi tidak mampu lagi untuk berenang ke tepi sehingga membutuhkan pertolongan untuk dapat mencapai tepi. Penolong memegang lengan korban secara berlawanan dengan tangan penolong yang akan membantu. Apabila peolong memegang dengan tangan kanan, lengan kiri korbanlah yang dipegang tepatnya di pangkal lengan. Posisi korban dalam keadaan terlentang dan penolong menarik korban dengan berenang menggunakan gaya dada.

\section{Wrist tow}

Wrist tow sama dengan armpit tow digunakan pada koraban yang masih sadar, namun bedanya hanya pada posisi pegangan penolong. Penolong memegang 
pada bagian pergelangan tangan dengan posisi bagian dalam tangan korban menghadap ke atas kemudian penolong memegang tangan korban dengan mengaitkan ibu jari dan jari telunjuk atau jari tengah di pergelangan tangan korban. Apabila tangan kanan korban yang dipegang, tangan kanan penolonglah yang digunakan untuk menarik korban. Kemudian, penolong membawa korban dengan menggunakan gaya dada dan hanya dengan bantuan satu tangan saja.

\section{Tired swimmer tow}

Teknik ini digunakan untuk menolong korban yang kelelahan di tengah perairan dan tidak sanggup untuk menepi, teknik ini digunakan pada korban yang masih dapat diajak komunikasi. Penolong berenang dengan gaya dada seperti biasa dan korban didorong ke tepi. Posisi korban telentang dengan kedua kaki disangkutkan pada pinggang korban dan kedua tangan berpegang pada bahu penolong.

Selain teknik tanpa menggunakan alat ada pula teknik pernyelamatan dengan menggunakan alat bantu. Penyelamatan dengan alat bisa digunakan pada korban yang tidak sadarkan diri yang sebelumnya diberikan pertolongan napas buatan. Cara pertolongan dengan alat bantu yaitu:

\section{Tube Rescue}

Tube rescue adalah alat pelampung yang terbuat dari bahan yang elastis dengan kedua ujungnya memiliki kaitan untuk menggunci saat membawa korban. Alat ini digunakan melingkari badan korban. Kait pada tube diletakkan pada punggung sehingga posisi korban dalam keadaan telentang. Penolong berenang ke tepi dengan menggunakan gaya crawl. Apabila korban dalam keadaan panik, korban didekati dengan memberikan tube terlebih dahulu setelah korban berpegang kemudian ikat badan korban dengan tube kemudian ditarik. Korban yang telah tidak sadar segera lingkarkan tube pada korban dan telentangkan korban dan segera memberi napas buatan sebisa mungkin untuk membuka jalan pernapasan setelah itu bawa korban ke tepi.

\section{Board Rescue}

Board rescue adalah alat yang menyerupai papan selancar. Papan ini digunakan untuk mengankut korban baik yang kelelahan maupun yang dalam keadaan tidak sadar. Cara mengendarai board rescue adalah dengan posisi bersimpuh

MEDIKORA Vol. II, No. 1, April 2006: 1 - 10. 
pada atas papan dan mengayuh dengan dua tangan secara bersama-sama, untuk melakukan pengereman dengan cara menurunkan kaki secara bersama dan mengambil posisi duduk dengan kedua kaki berada pada sisi yang berlainan. Cara yang kedua dengan posisi telungkup di atas papan dan mengayuh dengan satu tangan bergantian seperti gerakan tangan gaya crawl, untuk menghentikannya dengan mengayuh tangan ke arah depan secara bersama-sama. Setelah sampai di tempat korban yang dilakukan adalah mengangkat korban ke atas papan.

Cara mengangkat korban sadar, menghentikan papan dengan posisi korban berada di sebelah kanan papan. Kemudian, korban berusaha sendiri untuk naik ke atas papan dan penolong membantu serta mengimbangi agar papan tidak terbalik. Setelah berada di atas papan posisi korban tertelungkup dan penolong juga dalam posisi yang sama kemudian bersama-sama mengayuh board rescue.

Apabila korban dalam keadaan tidak sadar, penolong menghentikan papan dengan bagian kiri papan yang mendekat dengan korban. Raih tangan kiri korban dan letakkan pada tepi papan kemudian papan diputar sebanyak dua kali sehingga korban berada di atas papan dan benahi posisi korban untuk dapat dibawa ke tepi. Bantuan napas buatan juga dapat diberikan sebelum membawa korban ke atas papan dengan meletakkan kepala korban pada tepi papan dan kaki penolong turun dari sisi yang berbeda, setelah jalan pernapasan terbuka kemudian korban dinaikkan ke papan.

\section{KESIMPULAN}

Peristiwa kecelakaan dapat terjadi di mana saja dan dapat menimpa siapa saja. Dibutuhkan suatu keterampilan khusus agar dapat menyelamatkan korban. Dengan demikian, proses penyelamatan bagi diri sendiri maupun orang lain sangat perlu untuk dipelajari dan sangat bermanfaat untuk diterapkan di masyarakat.

Beberapa teknik dapat digunakan, baik untuk menyelamatkan diri sendiri maupun untuk menyelamatkan orang lain. Teknik yang digunakan untuk mempertahankan diri di perairan dengan cara menggunakan pelampung yang terbuat dari pakaian. Pakaian yang dapat digunakan sebagai pelampung antara lain celana, kemeja dan rok. Teknik yang digunakan untuk membawa korban antara lain 
adalah the hip carry rescue, armpit tow, wrist tow, dan tired swimmer tow. Penguasaan teknik penyelamatan diri sebaiknya dikuasai agar dapat mempertahankan diri.

\section{DAFTAR PUSTAKA}

Haller David. (1982). Belajar Berenang. Bandung: Pioneer Jaya.

Kartono Mohamad. (2003). Pertolongan Pertama. Jakarta: PT Gramedia Pustaka Utama.

Rob Orr, C and Tyler, Jane B. (1987). Dasar-dasar Renang. Bandung: Angkasa.

Sukintoko, Drs. (1983). Renang dan Metodik. Jakarta: PT. Persada Jaya Putra.

Surf Live Saving Australian. (2001). Surf Live Saving Manual Training. Surf Live Saving Ltd.

MEDIKORA Vol. II, No. 1, April 2006: 1 - 10. 